Original Paper

\title{
Kesiapsiagaan Bencana Gempabumi di SMP Negeri 2 Mataram
}

\section{Syahrial Ayub $^{1 *}$, Muh.Makhrus ${ }^{1}$, Jannatin Arduha ${ }^{1}$, Ni Nyoman Sri Putu Verawati ${ }^{1}$, Kosim $^{1}$}

${ }^{1}$ Program Studi Pendidikan Fisika, Fakultas Keguruan dan Ilmu Pendidikan, Universitas Mataram, Indonesia

DOI: $10.29303 /$ jpmpi.v2i1.328

Sitasi: Ayub, et, al. (2019). Kesiapsiagaan Bencana Gempabumi di SMP Negeri 2 Mataram. Jurnal Pengabdian Magister Pendidikan IPA (JPMPI). (2) 1. pp. 25-31

*Corresponding Author: Syahrial Ayub, Program studi pendidikan fisika, Fakultas Keguruan dan Ilmu Pendidikan, Universitas Mataram, Indonesia;

Email:

syahrial_ayub@unram.ac.id

\begin{abstract}
Abstrak: Lombok sebagai salah satu pulau di wilayah Indonesia yang sangat rentan terjadinya gempabumi. Tahun 2018 antara bulan Juli sampai Agustus pulau Lombok diguncang 4 kali gempa bumi berkekuatan besar, yaitu 29 Juli 2018 kekuatan 6,4 SR, 5 Agustus 2018 kekuatan 7 SR, 9 Agustus 2018 kekuatan 6,2 SR dan 19 Agustus 2018 berkekuatan 7 SR ditambah dengan rentetan gempa susulan yang mencapai 2500 kali. Hal ini terdampak luar biasa pada masyarakat di pulau Lombok. Bangunan, infrastruktur hancur dan korban ratusan korban jiwa pada rentetan gempa Lombok. Studi pendahuluan menunjukkan bahwa kesadaran masyarakat terhadap gempa bumi dan mitigasi gempa bumi sangat kurang. Gempa bumi merupakan peristiwa alam yang tidak dapat diprediksi kapan terjadinya sehingga bisa terjadi tiba-tiba seperti saat bekerja, tidur, bermain, dan bahkan juga saat belajar di sekolah. Peserta didik adalah kelompok yang paling rentan menjadi korban gempa bumi demikian juga guru dan perangkat sekolah lainnya. Maka dari itu mereka sangat perlu dibekali kesiapsiagaan gempa bumi supaya kerugian material dan jiwa dapat diminimalisir. Kegiatan ini merupakan implementasi model pembelajaran mitigasi bencana alam gempabumi yang dikembangkan oleh tim pengabdian. Kegiatan melibatkan 38 orang siswa kelas VIII/a, 1 orang guru SMP Negeri 2 Mataram. Hasil kegiatan menunjukkan bahwa siswa dan guru mengikuti kegiatan dengan sungguhsungguh, baik dalam bentuk mendengarkan informasi yang diberikan, pemutaran video, latihan-latihan dan simulasi kesiapsiagaan bencana gempabumi. Langkahlangkah penyelamatan diri yang harus dilakukan peserta didik adalah (1) lindungi kepala, (2) Jauhi kaca, (3) masuk kolong meja, (4) lari ke tempat terbuka. Namun demikian, mereka mengalami hambatan dalam memahami teknik penyelamatan diri dari gempa bumi dan pertolongan pertama pada korban bencana gempa bumi. Berdasarkan temuan tersebut, disarankan agar peserta didik dan guru melatih diri secara kontinu dan berkelanjutan supaya kesiapsiagaan bencana gempabumi di sekolah betul-betul melekat pada diri mereka, sehingga kesadaran siswa, guru terhadap bencana gempa bumi meningkat.
\end{abstract}

Kata kunci : Bencana; Gempa bumi; Kesiapsiagaan; Mitigasi.

\section{Pendahuluan}

Berdasarkan letak geografis, wilayah kepulauan Indonesia di tempat pertemuan 3 lempeng besar dunia, yaitu lempeng India-Australia (bagian Selatan), lempeng Eurasia (bagian Barat dan Utara), dan lempeng Pasifik (bagian Timur) (Anton, 2012), olehkarena itu Indonesia merupakan wilayah yang sangat rawan terjadinya gempa bumi. Menurut data rekaman sebaran episentrum gempa bumi dengan magnitudo 5 dari tahun 1900-2000 dan menurut peta daerah gempa bumi di Indonesia, propinsi NTB berada di wilayah 4. Wilayah tersebut merupakan wilayah yang rawan terhadap terjadinya gempa bumi. Selain, NTB berada di dekat pertemuan dua lempeng dunia, NTB juga 
berada di atas jalur gunung berapi yang aktif di dunia. Posisi ini menjadikan Mataram rentan terhadap bencana alam gempa bumi tektonik maupun volkanik. Gempa bumi dapat menimbulkan kerusakan harta benda, sarana prasarana, dan bahkan korban manusia yang terluka dan meninggal dunia. Bencana alam tersebut telah membuka mata semua elemen masyarakat secara nasional. Semuanya itu terjadi secara tiba-tiba tanpa bisa diprediksi oleh manusia. Dengan mengetahui bahwa gempa bumi belum bisa diduga secara ilmiah, perlu dilakukan usaha mengurangi resiko akibat yang ditimbulkan gempa bumi. Usaha-usaha yang dilakukan untuk mengurangi resiko gempa bumi disebut Mitigasi Bencana Alam Gempa Bumi (Brahmantyo, 2005). Kegiatan ini dilakukan pelatihan bagi siswa dan guru SMP Negeri 2 Mataram dengan tujuan meningkatkan pengetahuan dan keterampilan mereka dalam menghadapi ancaman bahaya gempa bumi serta memahami prosedur dan alat pertolongan pertama pada korban. Dalam kegiatan ini, implementasi kurikulum pendidikan mitigasi bencana alam gempa bumi yang diformulasikan dengan pengetahuan dan pengalaman masyarakat NTB yang disusun oleh tim, dalam menghadapi kejadian gempa bumi. Pengetahuan dan pengalaman masyarakat NTB yang telah diwariskan secara turun menurun untuk mengurangi resiko kejadian gempa bumi didefenisikan sebagai kearifan lokal masyarakat NTB dalam mitigasi bencana alam gempa bumi.

Ada berbagai bentuk kearifan lokal masyarakat NTB yang relevan dengan kajian gempa bumi yang berhasil diidentifikasi dan diformulasikan dalam kegiatan ini yang dikelompokkan menjadi dua, yaitu pemberitahuan kejadian gempa kepada orang lain dan pemberitahuan keadaan diri sendiri pada saat gempa terjadi. Ketika terjadi gempa masyarakat NTB umumnya berteriak lindur, lindur, lindur yang artinya terjadi gempa (Hidayati, 2005). Teriakan tersebut disampaikan ke orang lain yang ada disekitarnya untuk mengingatkan bahwa telah terjadi gempa. Diharapkan setiap orang menyadari telah terjadi gempa segera melakukan tindakan penyelamatan sesuai dengan keadaan setempat. Disamping berteriak, masyarakat juga memukul benda-benda yang mengeluarkan bunyi, umumnya kentongan, untuk mengingatkan bahwa telah terjadi gempa kepada masyarakat lain yang ada dikejauhan atau yang sedang ada di dalam rumah (Istiyanto, 2009). Untuk memberitahukan keadaan dirinya masyarakat umumnya berteriak supaya didengar oleh orang lain sehingga bisa secepatnya mendapatkan bantuan. Penggunaan kearifan lokal dalam mitigasi bencana alam telah banyak digunakan oleh masyarakat. Joko martono (2011) menyatakan bahwa memahami budaya lokal didaerah rawan bencana merupakan alternatif yang sangat masuk akal untuk mengurangi resiko bencana. Salah satu kebiasaan masyarakat yang bisa dirujuk adalah kebiasaan masyarakat di pulau Semeulue. Masyarakat di kepulauan Semeuleue terbiasa berteriak smong ketika air laut surut secara tiba-tiba karena hjal itu dipahami sebagai pertanda akan terjadi "ombak besar" yang dikenal dengan tsunami. Pada saat terjadi tsunami Aceh tahun 2004, yang menelan ratusan ribu korban nyawa manusia, masyarakat kepulauan Semeulue gampir tidak ada yang menjadi korban karena ketika air laut surut secara tiba-tiba masyarakat berteriak smong diikuti dengan berlari ke daerah yang lebih tinggi. Untuk memberikan pemahaman dan pelatihan kepada masyarakat khususnya siswa SMP tentang gempa bumi, akibatnya dan cara penyelamatan diri maka diberikan kegiatan mitigasi bencana alam gempa bumi. Kegiatan ini tertuang dalam tanggap bencana gempa bumi. Dalam pemberian materi tanggap bencana gempa bumi pada siswa SMP digunakan kurikulum pendidikan mitigasi bencana alam gempa bumi yang pernah dikembangkan oleh proyek DAPS bekerja sama dengan kementerian pendidikan nasional. Secara garis besar pengembangan kurikulum tersebut berisikan rumusan Standar Kompetensi (SK), kompetensi dasar (KD), Indikator Pencapaian Kompetensi (IPK) yang dapat dijadikan panduan pembelajaran atau pelatihan. Rumusan SK, KD dan IPK adalah sebagai berikut:

Tabel 1: SK, KD, dan IPK Kurikulum Pendidikan Mitigasi Bencana Alam Gempa Bumi

\begin{tabular}{lll}
\hline Standar Kompetensi & Kompetensi Dasar & Indikator Pencapaian Kompetensi \\
\hline $\begin{array}{l}\text { 1. Memahami hakekat } \\
\text { gempa bumi }\end{array}$ & $\begin{array}{l}\text { 1.1 mendeskripsikan hakekat } \\
\text { gempa bumi }\end{array}$ & - Mendefenisikan gempa bumi \\
& - Menggambarkan peristiwa akibat gempa bumi \\
$\begin{array}{l}\text { 2. Memahami akibat yang } \\
\text { ditimbulkan gempa bumi }\end{array}$ & $\begin{array}{l}2.1 \text { mendeskripsikan akibat } \\
\text { yang ditimbulkan gempa bumi }\end{array}$ & $\begin{array}{l}\text { - Mengelaskan peristiwa gempa bumi } \\
\text { - Mengelompokkan akibat gempa bumi }\end{array}$ \\
\end{tabular}




\begin{tabular}{|c|c|c|}
\hline Standar Kompetensi & Kompetensi Dasar & Indikator Pencapaian Kompetensi \\
\hline \multirow[t]{3}{*}{$\begin{array}{l}\text { 3. Memahami cara cara } \\
\text { mitigasi bencana alam } \\
\text { gempa bumi }\end{array}$} & $\begin{array}{l}\text { 3.1 mendeskripsikan cara cara } \\
\text { penyelamatan diri pada saat } \\
\text { gempa bumi }\end{array}$ & $\begin{array}{l}\text { - Mengidentifikasi cara penyelamatan diri ketika } \\
\text { terjadi gempa bumi } \\
\text { - Menjelaskan cara-cara penyelamatan diri ketika } \\
\text { gempa bumi } \\
\text { - Melakukan latihan menyelamatkan diri ketika } \\
\text { gempa bumi }\end{array}$ \\
\hline & & $\begin{array}{l}\text { - Mengidentifikasi cara-cara mengantisipasi } \\
\text { bencana alam gempa bumi }\end{array}$ \\
\hline & $\begin{array}{l}3.2 \text { mendeskripsikan cara-cara } \\
\text { mengantisipasi bencana alam } \\
\text { gempa bumi }\end{array}$ & $\begin{array}{l}\text { - Mengambarkan peta evakuasi } \\
\text { - Membuat model antisipasi penyelamatan diri } \\
\text { pada saat gempa bumi }\end{array}$ \\
\hline
\end{tabular}

Selain dalam bentuk deskripsi SK, KD, dan IPK, kurikulum pendidikan mitigasi bencana alam gempa bumi juga dilengkapi dengan uraian materi pelatihan. Cara pelaksanaan pelatihan terdiri atas materi teoritis berupa pemahaman siswa terhadap hakekat gempa bumi, cara melakukan mitigasi, dan prosedur pertolongan pertama korban gempa bumi, serta materi praktek berupa cara melakukan mitigasi diri dan orang lain. Berdasarkan analisis situasi pada pendahuluan ini, maka rumusan masalah dalam pengabdian kepada masyarakat ini adalah: 1) Bagaimana menyampaikan materi teori tentang gempa bumi pada siswa dan guru SMP N 2 Mataram?. 2) Bagaimana langkah-langkah penyelamatan diri dari bencana gempa bumi pada siswa dan guru SMP N 2 Mataram bila terjadi saat pembelajaran di kelas?

Permasalahan yang dihadapi mitra dapat diselesaikan dengan mengadakan kegiatan pengabdian masyarakat di tempat itu. Langkahlangkah kegiatan pengabdian yang dilaksanakan adalah: 1) Observasi ke sekolah mitra untuk menggali kebutuhan siswa, guru dan perangkat sekolah lainnya tentang tanggap bencana gempabumi. 2) Menyusun modul pelatihan penerapan iptek untuk meningkatkan tanggap bencana gempa bumi yang berisi: (a) materi tentang konsep gempabumi dan langkah-langkah pembelajarannya di kelas dengan integrasi kurikulum 2013, (b) materi tentang teknik penyelamatan diri bila terjadi gempabumi jika siswa sedang berada di sekolah atau lagi belajar, (c) materi tentang prosedur dan alat pertolongan pertama pada korban gempabumi, (d) Rekomendasi integrasi materi tanggap bencana gempabumi pada kurikulum 2013. 3) \Melakukan kegiatan pelatihan bagi siswa, guru dan perangkat sekolah lainnya sesuai dengan modul yang sudah disusun. Materi pelatihan mencakup teori dan praktek yang diharapkan mampu meningkatkan pengetahuan, sikap dan keterampilan terhadap tanggap bencana gempabumi. 4) Melakukan evaluasi kegiatan yang telah dilakukan untuk mendapatkan informasi tentang kelemahan dan keunggulan kegiatan. 5) Refleksi terhadap evaluasi yang telah dilakukan sehingga indikator pencapaian yang ditentukan tim tercapai.

Intinya, bila siswa dan guru diberi perlakuan seperti langkah-langkah solusi permasalahan di atas siswa dan guru dapat bersahabat dengan gempa bukan takut atau menyalahkan gempa itu sendiri. Pengabdian ini juga mampu menghasilkan buku tentang kesiapsiagaan bencana gempa bumi bagi masyarakat sekolah dan hasilnya diterbitkan pada jurnal pengabdian.

Target keluaran yang dicapai pada kegiatan pengabdian ini adalah: 1) Tertanamnya kesadaran yang mendalam tentang tanggap bencana gempabumi pada siswa, guru dan perangkat sekolah lainnya serta imbasnya pada masyarakat sekitar. 2) Modul pelatihan tanggap bencana gempabumi yang baku sesuai dengan kebutuhan siswa, guru dan perangkat sekolah. 3) Rekomendasi pada pemegang kebijakan pendidikan tentang integrasi tanggap bencana pada kurikulum sekolah dasar. 4) Memperkenalkan kearifan lokal masyarakat NTB dalam tanggap bencana gempabumi pada masyarakat sekolah. 5) Menghasilkan alat-alat sederhana dari lingkungan yang dapat dimanfaatkan untuk tanggap bencana gempabumi dan 
pertolongan pertama pada korban. 6) Artikel ilmiah dalam prosiding atau jurnal pengabdian ber-ISSN.

\section{Metode Pelaksanaan}

Secara keseluruhan, kegiatan ini dilaksanakan dengan tahapan: 1) Melakukan pembelajaran tentang pengetahuan gempa bumi, mitigasi gempa bumi dan prosedur pertolongan pertama pada korban gempa bumi, 2) Simulasi penyelamatan diri dari gempa bumi bila berada di dalam kelas, 3) Pemutaran video tentang tanggap bencana gempa bumi. Kegiatan ini melibatkan siswa dan guru SMP Negeri 2 Mataram dengan perincian kegiatan: Pertama, siswa diajak berdiskusi tentang kejadian gempa bumi, dilanjutkan dengan kegiatan menggambar peristiwa yang terjadi saat terjadi gempa bumi, dan diakhiri dengan kegiatan menjelaskan gambar yang dibuat di depan kelas. Kedua, siswa diajak berdiskusi tentang akibat dari gempa bumi, dilanjutkan dengan kegiatan menggambar berbagai peristiwa akibat gempa bumi, dan diakhiri dengan kegiatan menjelaskan gambar yang dibuat di depan kelas. Ketiga, siswa diajak untuk berdiskusi tentang cara mengamankan diri ketika terjadi gempa bumi disertai dengan latihan penyelamatan diri dan melakukan pertolongan pertama kepada penderita korban. Keempat, siswa diajak berdiskusi tentang tempat-tempat yang aman untuk melindungi ketika terjadi gempa bumi dan diakhiri dengan membuat peta evaluasi yang dibuat di depan kelas. Kelima, setelah semua kegiatan selesai, siswa diberikan tes tertulis dalam bentuk isian singkat. Seluruh kegiatan pelatihan dipandu dengan unit-unit pembelajaran.

Ada lima unit pembelajaran yang disiapkan pelatihan mitigasi bencana alam gempa bumi, yaitu: 1) Hakikat Gempa Bumi, 2) Akibat Gempa Bumi, 3) Cara penyelamatan Diri Saat Terjadi Gempa Bumi, 4) Cara Mengantisipasi Gempa Bumi, dan 5) Model Antisipasi Gempa Bumi. Kearifan lokal masyarakat NTB dalam mitigasi bencana alam gempa bumi menjadi bagian isi dari unit-unit pembelajaran yang diberikan. Pada pelatihan ini, hanya empat unit yang disampaikan. Unit terakhir, yaitu Model Antisipasi Gempa Bumi belum didiskusikan karena masalah teknik di lapangan. Salah satu contoh unit pembelajaran yang digunakan adalah sebagai berikut.

Kegiatan pelatihan menggunakan pendekatan partisipatif yang mengajak siswa secara aktif berpartisipasi dalam pelatihan melalui mendengarkan informasi, memberi tanggapan (respon), menggambarkan peristiwa, dan mempersentasikan ide atau pemahamannya melalui gambar. Langkah-langkah kegiatan pembelajaran dijelaskan pada Tabel 2.

Tabel 2: Langkah-Langkah Kegiatan Pembelajaran Tanggap Bencana Gempabumi

\begin{tabular}{ll}
\hline Tahapan & Kegiatan pelatihan \\
\hline Kegiatan awal & Tim memutar video tentang proses terjadinya gempa bumi. Tim mengajukan pertanyaan- \\
& pertanyaan untuk menggiring siswa pada permasalahan. Siswa diharapkan terpancing bertanya: \\
1) Dampak-dampak apa saja yang ditimbulkan oleh bencana gempabumi? & 2) Langkah-langkah apa yang harus ditempuh oleh siswa dan guru bila terjadi gempa saat \\
pembelajaran di kelas? & Tim meminta jawaban-jawaban sementara siswa terhadap permasalahan yang ditemukan? \\
& Tim kemudian mengajak siswa melakukan kegiatan berikut: \\
Kegiatan inti & Tim membagikan gambar-gambar kepada siswa, dimana gambar-gambar itu berisi 2 konsep \\
& yaitu: dampak gempa bumi dan langkah langkah penyelamatan diri dari gempabumi bila \\
2. Terjadi gempabumi saat mereka sedang belajar di sekolah. \\
untuk menjelaskan gambarnya kepada teman-temannya.
\end{tabular}




\begin{tabular}{ll}
\hline Tahapan & Kegiatan pelatihan \\
\hline Kegiatan Akhir & $\begin{array}{l}\text { Tim bersama siswa dan guru mensimulasikan langkah-langkah penyelamatan diri bila terjadi } \\
\text { gempabumi saat pembelajaran di kelas }\end{array}$ \\
$\begin{array}{l}\text { Timenutup pelajaran dengan mengajak semua siswa untuk merangkum hasil kegiatan belajar } \\
\text { pembelajaran di kelas. }\end{array}$ \\
Tim mengajak siswa, guru bernyanyi tentang siaga bencana.
\end{tabular}

(Syahrial A,2019)

Penilaian hasil kegiatan pelatihan dilakukan dalam dua bentuk yaitu penilaian partisipasi selama kegiatan dan penilaian penguasaan materi di akhir pelatihan. Penilaian partisipasi dilakukan melalui pengamatan, sedangkan penilaian penguasaan materi dilakukan melalui tes tertulis. Pedoman pengamatan partisipasi dan tes penguasaan materi disediakan secara terpisah. Hasil penilaian partisipasi dalam kegiatan dituliskan dalam bentuk deskripsi deng kategori sebagai berikut: Berpartisipasi cukup, apabila peserta pelatihan mengikuti pelatihan secara penuh (dengan simbol +). Berpatisipasi baik, apabila peserta pelatihan mengikuti pelatihan secara penuh dan sesekali memberi tanggapan (bertanya atau menjawab) terhadap materi yang disampaikan (dengan simbol ++ ). Berpatisipasi sangat baik, apabila perserta mengikuti pelatihan secara penuh dan beberpa kali memberi tanggapan (bertanya atau menjawab) terhadap materi pelatihan (dengan simbol +++).

\section{Hasil dan Pembahasan}

Kegiatan pengabdian masyarakat tentang kesiapsiagaan gempabumi di SMP Negeri 2 Mataram menghasilkan tanggap bencana gempabumi pada siswa dan guru meningkat. Hal ini sangat terlihat pada respon mereka pada saat simulasi dilakukan. Simulasi ini dilakukan saat penerapan model pembelajaran mitigasi bencana di sekolah pada siswa dan guru. Video kegiatan pembelajaran dapat dilihat di youtube dengan link https://www.youtube.com/watch? $v=0$ oxH $2 W 2 t Z Q A$ $\& t=58 \mathrm{~s}$. Pada video ini terlihat bahwa siswa dan guru mendapatkan informasi, gambaran dan simulasi penyelamatan diri dari gempabumi bila terjadi saat pembelajaran di kelas.

Pada kerja kelompok terdapat 2 konsep: (1) dampak bencana gempabumi yaitu bangunan runtuh, korban luka dan jiwa, tanah retak dan tsunami, (2) langkah-langkah penyelamatan diri bila terjadi gempabumi saat pembelajaran di kelas, yaitu lindungi kepala, jauhi kaca atau benda benda berat lainnya, masuk ke kolong meja, bersiap dan lari ke ruang terbuka. Berdasarkan pengamatan langsung dan wawancara yang dilakukan terungkap bahwa kegiatan ini sangat bermanfaat karena telah memberikan pengetahuan dan contoh nyata tentang gempa bumi, langkah-langkah penyelamatan diri dari gempabumi bila terjadi saat pembelajaran di kelas.

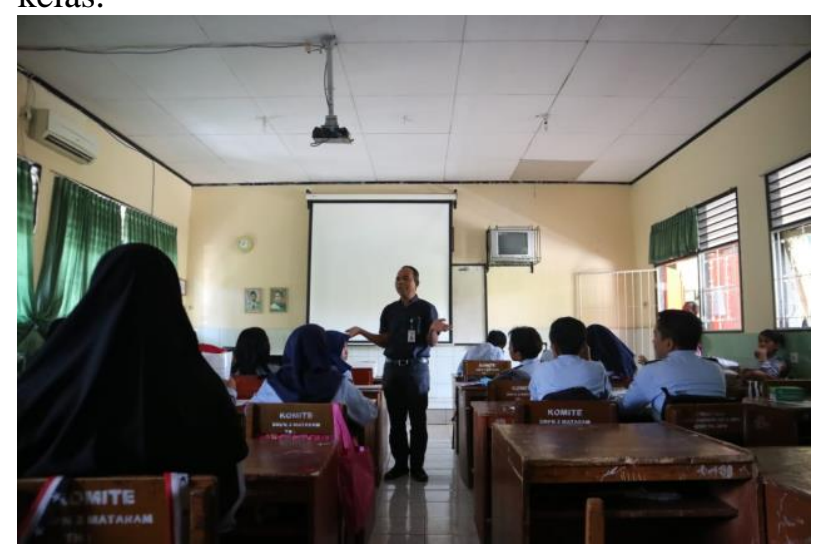

Gambar 1. Proses Pembelajaran di Kelas

Peserta berharap kegiatan ini dapat dilanjutkan secara kontinu dan lebih optimal lagi. Siswa yang 38 orang dan 2 orang guru mengikuti pelaksanaan pelatihan secara sungguh-sungguh, baik dalam mendengarkan informasi maupun dalam melakukan praktik-praktik yang diberikan. Materi pendidikan dan pelatihan yang disampaikan ada empat, yaitu hakikat gempa bumi, akibat yang timbulkan, cara penyelamatannya diri saat terjadi gempa bumi, dan cara mengantisipasi kejadian gempa bumi. Informasi disampaikan dengan metode diskusi kelas dan tanya jawab. Praktikpraktik yang dilakukan selama pelatihan terdiri atas pelatihan menggambar berbagai peristiwa yang terkait dengan gempa bumi, ke luar kelas, dan di luar kelas, serta praktik memberikan pertolongan pertama kepada penderita korban.

Di awal kegiatan, siswa terlihat sedikit tegang kerna berhadapan dengan orang baru 
(pelatih) sehingga pelatih perlu beberapa saat untuk melakukan penyesuaian diri. Siswa tidak mau menjawab pertanyaan-pertanyaan yang disampaikan walaupun yang sederhana. Keadaan tersebut lalu dipecahkan dengan memberikan motivasi berupa hadiah kepada siswa yang mau menjawab pertanyaan yang disamapikan pelatih. Hadiah-hadiah yang diberikan berupa alat-alat pelajaran sederhana, seperti penggaris, penghapus, pensil, dan pulpen yang disampaikan sebagai bahan-bahan pelatihan. Hal tersebut ternyata mampu mencairkan suasana dan siswa mulai mau berprestasi dalam merespon pertanyaan-pertanyaan yang diberikan. Kegiatan-kegiatan tersebut dilakukan dengan cara yang sama untuk tiga materi pendidikan dan pelatihan lainnya, yaitu akibat gempa bumi, cara penyelamatan diri saat gempa bumi.

Tampak bahwa sebagian besar siswa sudah memiliki pengetahuan untuk penyelamatan diri ketika terjadi gempa. Hal tersbut dapat dilihat dari kecepatan mereka menerima dan mengikuti petunjuk yang diberikan. Misalnya, ketika mereka dilatih untuk berlindung di bawah meja saat terjadi gempa, dalam waktu singkat mereka bisa melakukannya dengan baik. Dalam praktik pemberikan pertolongan kepada korban yang dilakukan dalam bentuk pemberian obat merah dan membalut luka, terlihat beberapa siswa masih menunjukan keraguan untuk melakukannya. Namun dengan bimbingan pelatih, mereka mampu melakukannya dengan baik.

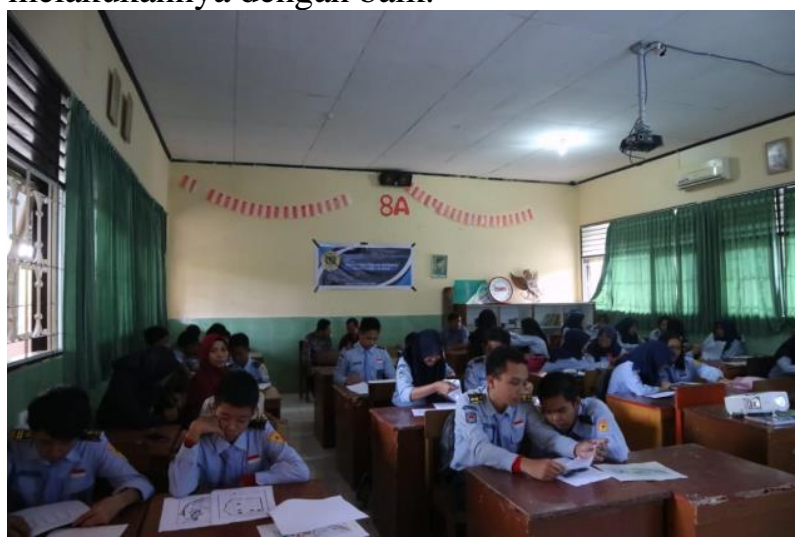

Gambar 2. Proses Pembelajaran dalam Kelas

Berdasarkan wawancara dan pengamatan langsung di lapangan pada akhir kegiatan, diperoleh informasi sebagai berikut (1) materi yang disampaikan menarik, terdapat ilmu yang sangat berarti tentang gempa bumi, mitigasi gempa bumi dan prosedur pertolongan pertama terhadap korban gempa bumi, (2) menambah pengetahuan dan keterampilan dalam penyelamatan diri bila terjadi gempa dan menolong orang lain yang menjadi korban gempa bumi, (3) melatih reflek dalam melakukan langkah-langkah penyelamatan diri dan orang lain bila tiba-tiba terjadi gempa bumi, (4) meningkatkan kesadaran akan bencana gempa bumi bagi siswa dan guru.

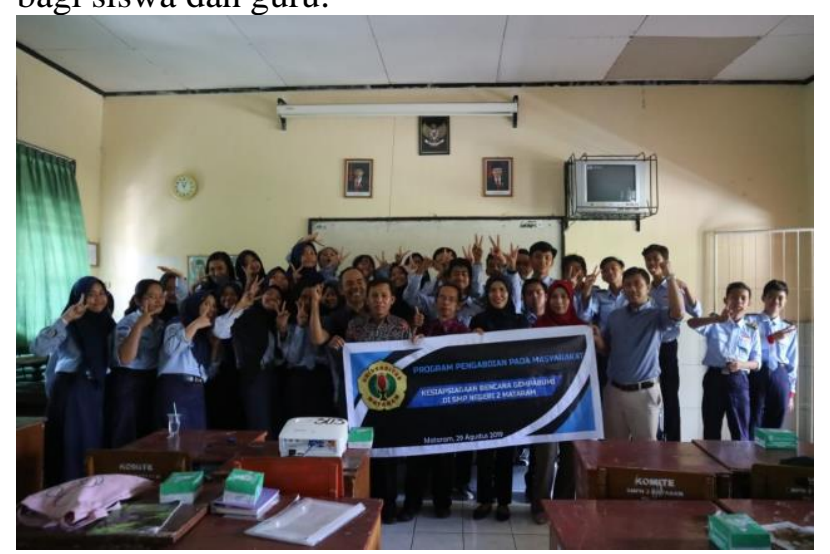

Gambar 3: Foto Bersama dengan Peserta Kegiatan

\section{Kesimpulan}

Kegiatan pengabdian pada masyarakat berupa kesiapsiagaan bencana gempa bumi bagi siswa dan guru SMP Negeri 2 Mataram sangat bermanfaat bagi peserta karena memberikan pengetahuan teoritis dan praktek tentang gempa bumi, mitigasi gempa bumi dan prosedur pertolongan pertama terhadap korban gempa bumi. Hal ini akan meningkatkan kesadaran dan tanggap terhadap bencana alam terutama gempa bumi di sekolah, sehingga diharapkan mampu meminimalkan dampak negatif dari gempa bumi.

\section{Saran}

Kegiatan ini sebaiknya lebih sering dilakukan dan melibatkan komunitas sekolah yang lebih banyak.

\section{Daftar Pustaka}

Anton, W. 2012 Pakar: Mitigasi Bencana Masuk Kurikulum Pendidikan. http:www.aktual.co/sosial/144525pakarmitigasi-bencana-masuk-kurikulumpendidikan. Diunduh 16 juni 2013 
Brahmantyo, B. D. J. (2005). Mengenal dan Mengantisipasi Alam Geologis. Pustaka Setia: Bandung.

Hidayati. (2005). Panduan Merintis Siaga Bencana Berbasis Masyarakat. Jakarta: LIPI

Istiyanto, Dinar, C. Sutikno, Pramono, Hadi (Ed.) 2009. Panduan Mitigasi Bencana Alam Tsunami. Badan Koordinasi Survey dan Pemetaan Nasional. Projek Penelitian dan Pengembangan Teknologi Survei danPemetaan danPusat Studi Bencana Universitas Gadjah mada: Yogyakarta

Joko, M. (2011). Mitigasi Bencana dalam Perspektif Komunikasi Berkearifan Lokal. Artikel kompasiana http://wwwsosbud.kompasiana.com.

Lilik, K, Ridawan, Y, Robi, A., Narwawi, P. (2011). Indek Rawan Bencana Indonesia. Badan Nasional Penanggulangan Bencana (BNPB)

Subagia, I, W, dan Wiratma, I G.L. (2013). Mitigasi Becana Alam Gempa Bumi Makalah. Disampaikan dalam Seminar Nasional Research Inovatif (Seminar-1) yang dilaksanakan oleh Lembaga Pengabdian UNDIKSHA.

Subagia, I, W, dan Wiratma, I G.L. (2012). Kurikulum Mitagasi Bencana Alam Gempa Bumi Berbasis Kearifan Lokal Masyarakat Bali. Makalah. Disamapikan dalam Seminar Nasional FMIPA UNDIKSHA.

Subagia, I. W., Wiratma, I G. L., Sudita, I, K. (2014). Materi Peltihan Mitigasi Bencana Gempa Bumi Berbasis Kearifan Lokal Masyarakat Bali. Singaraja: Undiksha Press

Syahrial, A. (2019). Bencana Alam Gempabumi (Di Lengkapi dengan RPP). Duta Pustaka Ilmu: Mataram. 